\title{
L) LUNiffith
}

Griffith Business School

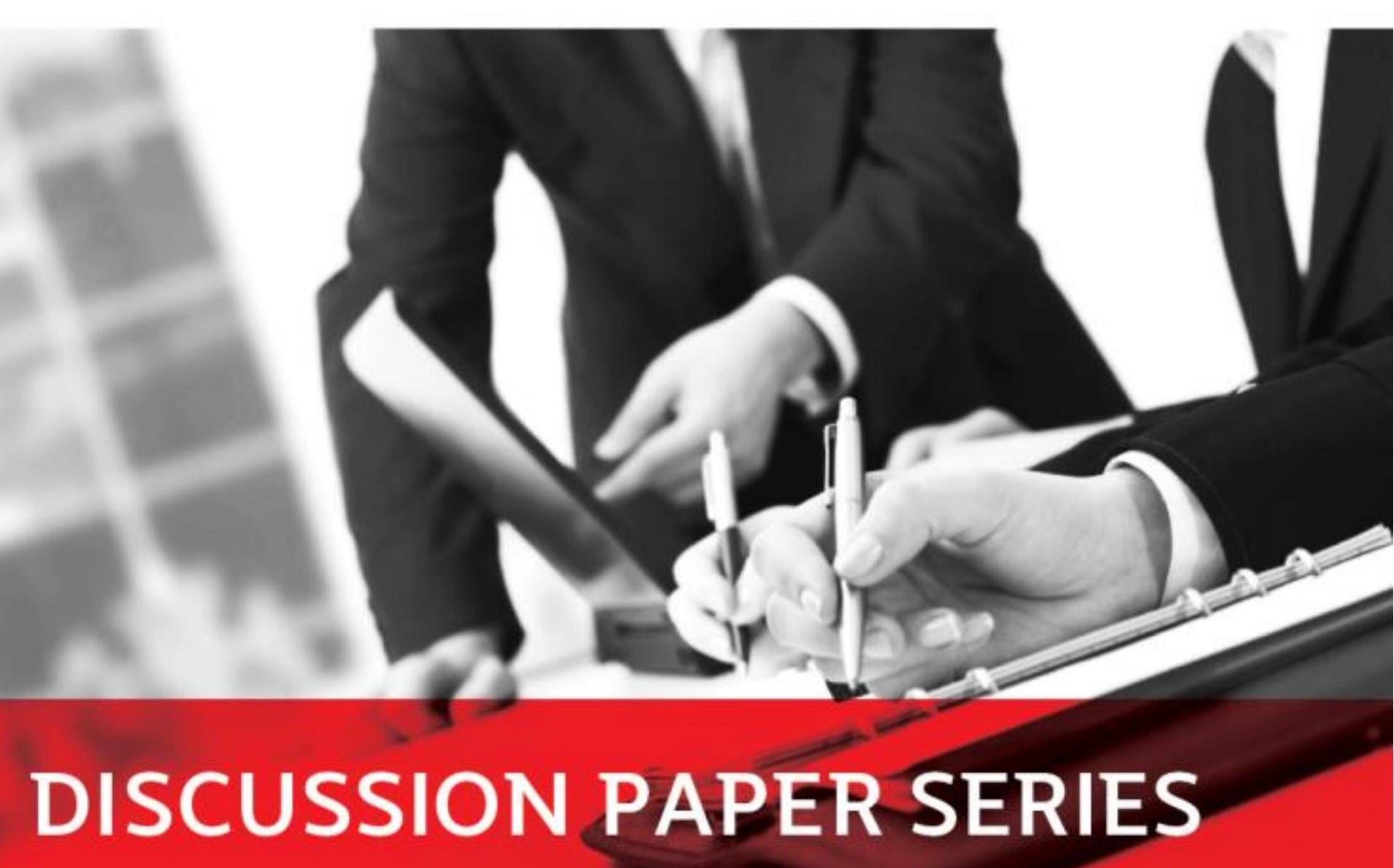

Finance and financial planning

\section{Determinants of student success in finance courses}

Alexandr Akimov, Sonja Kobinger and Mirela Malin

No. $2017-01$ 


\title{
Determinants of student success in finance courses
}

\author{
Alexandr Akimov*, Sonja Kobinger and Mirela Malin \\ Department of Accounting, Finance and Economics, \\ Griffith University, Southport 4222, Australia
}

\section{Abstract}

In the competitive landscape of higher education, student success is becoming an ever more important element in achieving and maintaining university reputation, accreditation and quality of teaching. Investigating the determinants of student success can help with better course design, adaptation of teaching techniques and program improvements. In this study, we examine students' use of the learning resources available to them and whether they have a significant impact on students' success in an undergraduate finance course. We find that class attendance, the online streaming of recorded classes, and reading the relevant textbooks all remain important strategies to achieve course success even after controlling for students' cognitive and English language abilities.

Key words: Academic success, teaching strategies, finance education, online teaching, class attendance

JEL Codes: A20, G21, I23

*Corresponding author. Tel. +61 7 55528579, Fax: +61 7 55528068, Email:

a.akimov@griffith.edu.au 


\section{Introduction}

Higher education has experienced an increasingly competitive environment in recent years, due to changing technologies, student demands and faculty requirements. Universities are viewing students as 'clients', where business success represents the number of graduands and students' achievement is analogous to customer satisfaction. Student success is an important element in achieving and maintaining university reputation, accreditation and quality of teaching. Investigating the determinants of student success can help with better course design, adaptation of teaching techniques and improvement of programs. Early research investigating the factors that influence performance has been conducted in the fields of economics (Anderson, Benjamin, \& Fuss, 1994; Bosshardt \& Watts, 1990; Laband \& Piette, 1995), accounting (Graves, Nelson, \& Deines, 1993; Murphy \& Stanga, 1994), criminal justice (Leiber, Crew, Wacker, \& Nalla, 1993) and finance (Paulsen \& Gentry, 1995). Since then, various studies have explored different predictors of student performance as potential influencers of student success, together with students' perceptions and expectations, teaching techniques and strategies, learning styles, and school, department and faculty characteristics.

In the current world of digital media, online resources and strategies have been playing an ever increasing role in delivering educational material. The penetration of the digital world into education has been multi-faceted: from using digital resources to supplement existing face-to-face strategies and providing better engagement in the class to entirely online delivery of individual classes, courses or whole programs. The effectiveness of using online resources in delivering better outcomes for students and whether online tools play a complementary or substitutive role are matters of debate.

In this paper, we tackle a number of research questions related to the effectiveness of a variety of existing learning resources/strategies in an undergraduate finance course. Firstly, we investigate the level of uptake (use) of the existing strategies by the students, that is, how many face-to-face classes are attended; lecture slides and tutorial exercises downloaded, and recorded lectures streamed. Secondly, we examine which of the existing resources/strategies make a significant contribution to the success of the students in the course. Thirdly, we compare the use and effectiveness of face-to-face and online strategies and draw some conclusions about complementarity and substitutability of those strategies/resources.

The paper consists of six main sections. Following this introduction, Section 2 reviews existing theoretical and empirical literature. Section 3 outlines the analytical approach and 
methodology used. Section 4 discusses the findings as to the evidence of students' preferred resources/strategies. In Section 5, we use regression analysis to identify the teaching strategies that contribute to the success of the students in a finance course. The paper's conclusions are described in Section 6.

\section{What determines student's success in studying finance courses?}

Finance courses are central to programs in all business schools, and successful completion of these courses ensures adequate skill development and expert knowledge for students to enhance their employment opportunities in the field. Because of the quantitative and analytical nature of finance, students often find these courses more challenging compared to other courses. Thus, to help students achieve success, it is imperative that instructors understand the factors that influence student performance in these courses. Research in this area has revealed that previous finance knowledge and quantitative skills, demographics, effort, and Grade Point Average (GPA) score have an impact on student performance. As with other fields, changes in business education should be justified by evidence derived from research, and be supported by a theoretical framework at the same time.

\subsection{Theoretical foundation}

The taxonomy of student learning is closely linked with theoretical notions of teaching and instruction, creating a constant interaction between learning and teaching. Thus, it is hardly surprising to find that among the most direct influencers of student success are the characteristics of teaching styles, classroom activities and instructor interactions with students. Wang, Haertel, and Walberg (1993) employed a meta-analysis of 179 handbook chapters and reviews, 91 research syntheses, and 61 educational researchers' surveys to develop a conceptual framework for the most significant influences on student learning. This analysis established 28 classifications of variables for which a score was given to represent their degree of influence on learning. These variables were grouped into six categories: Student Aptitude, Classroom Instruction and Climate, Home and Peers Context, Program Design, School Organization, and State/District Characteristics. Figure 1 summarizes all the variables that influence learning, together with their individual and group scores. The results of the study reveal that direct influences (psychological, instructional and contextual) had the most impact on learning, as opposed to indirect influences (school or district policies or state and organizational features). As a group, student aptitude was the most influential on 
learning, while the highest variable scores were allocated to classroom management (teachers' strategies to maintain active participation by all students), metacognitive processes (planning, testing, revising, and evaluating learning strategies), cognitive processes (level of specific academic knowledge in subject area), home environment/parental support (parental involvement in ensuring homework is completed) and student and teacher social interactions (positive student interactions with teachers and other students). The study highlights the importance of student and teacher actions and home environment on learning success, while program, school, state and district policies have limited effect on those (teachers and parents) involved in students' achievements.

In a similar vein, Pintrich (1994) found that a student's knowledge base, procedural skills, self-regulation of learning, and motivation and affect are common elements in the components of learning taxonomies. Cognitive processing activities (thinking of examples, looking for applications) have a direct influence on learning outcomes, and affecting activities (motivating oneself, blocking emotions) can positively or negatively influence the learning process. On the other hand, regulation activities indirectly influence learning outcomes through the diagnosis of causes of learning difficulties and thus change in those learning activities. Vermunt $(1996,1998)$ combines these processing and regulation strategies with student conceptions of learning (learning objectives, strategies and tasks) and learning orientation (personal goals, attitudes, expectations, concerns and doubts) into four learning styles or patterns: undirected, reproduction-directed, meaning-directed and applicationdirected. As expected, high-quality learning occurs when meaning- and application-directed learning styles are applied.

The 3P model of Biggs (1989) describes the learning process as an interaction of three sets of variables: student characteristics and learning environment (presage), students' approach to learning (process) and learning outcomes (product). Presage factors are the prior knowledge, academic ability and personality of the student, as well as the teaching methods, workload and course structure.

Figure 1. Influences on Student Learning (adapted from Wang, Haertel, \& Walberg, 1994)

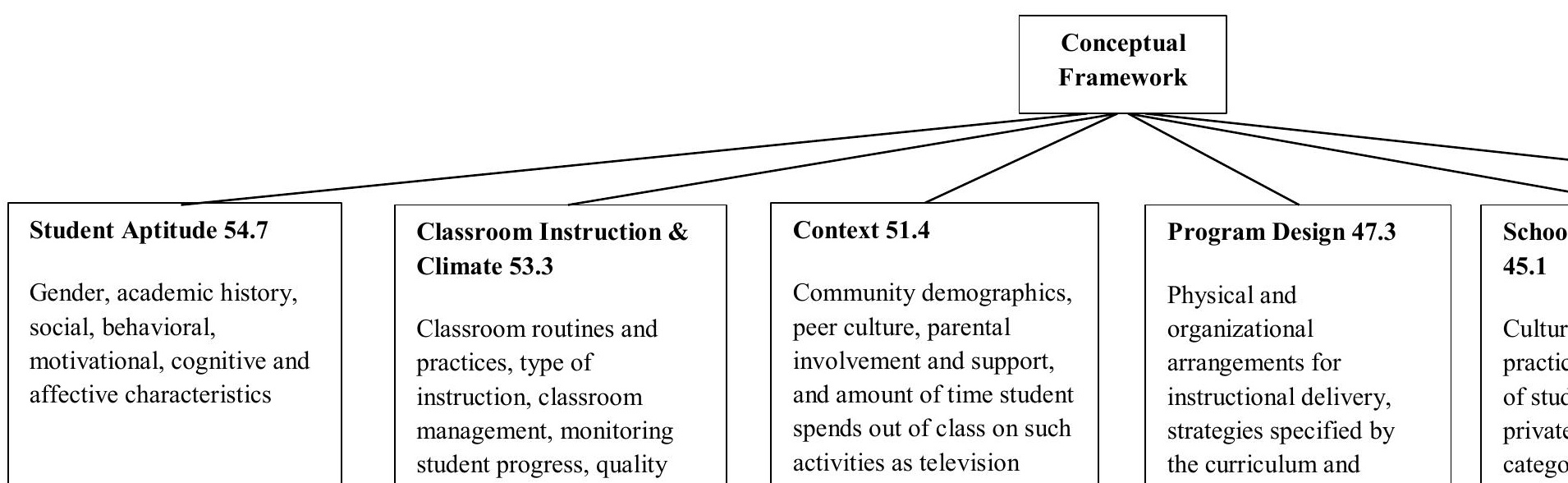


Process factors define the approach to learning, determining whether students adopt a 'deep' or 'surface' attitude (Marton \& Säljö, 1976; Thomas \& Bain, 1984), while product factors are described through assessment scores, skill development or course satisfaction. Lizzio, Wilson, and Simons (2002) found that among the presage factors, perceptions of heavy workload and inappropriate assessment led toward a superficial learning process, while perceptions of good teaching influenced students toward a deeper approach to learning.

Similarly to the learning processes and strategies adopted by students, research has also identified teaching functions that promote high-quality student learning. From a teacher's perspective, the processing function relates to the way subject content is presented and clarified, and the affective function refers to the creation and maintenance of a positive, motivational and emotional climate for learning, while the regulation function involves the way teachers guide students' learning processes (Vermunt \& Vermetten, 2004). Thus, good teaching activities are those that promote a 'deep' approach to learning and include explaining the relationship with the subject matter, giving examples, planning, monitoring students' progress and motivating students (Rosenshine \& Stevens, 1986).

Given advances in technology and the rapid shift of the learning environment toward online education, numerous contemporary approaches to learning and classroom instruction have evolved. Research has emerged that investigates the techniques and methods used by teachers to make classes more interesting and engaging in these new environments. These include integrating multimedia into content to improve student attention in the lecture (Berk, 2009; Hoffman \& Ritchie, 1997), using electronic voting systems that allow real-time communication between students and teachers (Caldwell, 2007; Draper \& Brown, 2004), and employing social media to foster collaboration (Kaufer, Gunawardena, Tan, \& Cheek, 2011; Ford, Bowden, \& Beard, 2011). Overall, studies find that students demonstrate higher learning and understanding, attend class more, and engage better when collaborative or interactive teaching methods are adopted when compared to the use of traditional styles of teaching (Slavich \& Zimbardo, 2012).

These recent advances in classroom instruction can be characterized as principles of learning that guide instruction (active and student-centered learning) and methods of instruction (collaborative, experiential and problem-based learning) (Slavich \& Zimbardo, 2012). Active learning comprises those activities that engage higher-order cognitive strategies such as analysis, evaluation and synthesis (Svinivki \& McKeachie, 2011; Smith et al., 2009). On the other hand, student-centered learning depends on the instructor's ability to modify the course and content based on students' needs, abilities, interests and learning styles (Brown Wright, 2011; Kilic, 2010). At the teachingmethod level, collaborative learning involves the concept that working in groups is more dynamic 
and motivating than working alone, which helps students recognize gaps in their understanding and encourages them to reorganize their own knowledge of concepts (Cooper, 1999; O'Donnell, 2006). Experiential learning engages students in activities that allow them to experience the course content and involves playing games or simulations, conducting interviews or experiments, or keeping a journal (Akimov \& Malin, 2017; Beard \& Wilson, 2006; Kolb \& Kolb, 2009). In problem-based learning, the instructor acts as a facilitator who guides the learning process, and maximizes students' responsibilities for learning through complex, multilayered problems (Amador, Miles, \& Peters, 2006; Loyens, Magda, \& Rikers, 2008). These approaches to learning and classroom instruction have in common the constructivist and social constructivist theories from which they originate, which highlight the significance of active engagement and social interactions in encouraging learning (Piaget, 1926; Vygotsky, 1986). Have the theoretical principles of learning and methods of instruction been successfully applied in practice? Is there confirmation that student performance is enhanced as a result of adopting contemporary approaches to teaching? The next section provides evidence from research conducted in the higher education area, paying particular attention to the factors that influence student success in business- and finance-related courses.

\subsection{What does empirical evidence tell us?}

The nature of business and commerce degrees, in particular finance and economics majors, demands that students develop 'analytical abilities' and 'problem-solving' skills. Finance courses are, essentially, a form of applied mathematics where higher-order skills are developed and are necessary to succeed. Orlov and Roufagalas (2012) attempted to measure students' abilities to think more deeply through a 'Cognitive Reflection Test' (CRT) and to assess whether this influenced exam performance. They found a positive relationship between CRT score and student performance in higher-level economics courses, and students with high CRT scores outperformed those students with low CRT scores. In contrast to previous studies, Orlov and Roufagalas (2012) found that female students performed about $3 \%$ better than males and attendance had a statistically significant effect on performance.

Although student human capital in the form of entrance exam scores, GPAs and analytical abilities has been known to have a positive effect on performance, other factors, such as student inputs in the form of lecture attendance and study time, influence students' academic results as well. The causal effect of study time on performance has been investigated by Stinebrickner and Stinebrickner (2008), Bonestrønning and Opstad (2012), and Andrietti and Velasco (2015), confirming that effort spent on studying is an important determinant of success. Similarly, Marburger (2001), Chen and Lin (2008), Cohn and Johnson (2006), Stanca (2006), and Dobkin, Gil, and Marion (2010) found that lecture attendance had a positive impact on exam scores. This result is in line with the well- 
known fact that the more conscientious and motivated students are the ones who attend lectures more regularly, which ultimately leads to achieving higher grades in the course.

From a teacher's perspective, lecturing is established as the most common method of conveying content to students. Goffe and Kauper (2014) surveyed 275 instructors in the principles of economics about their chosen teaching methods, finding that a third of respondents favored lecturing purely because of having the ability to control the delivery and content. Another third of the participants favored lectures as a teaching method only because it was regarded as cost-effective when compared to the effort and time involved in preparing alternatives. The remaining third of the sample preferred non-lecture methods of teaching as they believed these promoted active learning and higher-order thinking.

The introduction of web-based learning technologies in higher education has resulted in the use of online recorded lectures as additional learning material. The specified benefits of lecture recordings include students' ability to revisit content, to use them as a study tool before examination, and to provide flexibility for those who work and study at the same time. However, Williams, Birch, and Hancock (2012) found that viewing lecture recordings instead of attending live lectures led to poorer performance in a microeconomics final exam. Their study found that greater live attendance at lectures was associated with higher marks, and also reported that lecture recordings were valuable to those students who already attended live lectures, making recordings a tool complementary to lecture attendance rather than a substitute for it.

Burgan (2006) also views lecturing as an important aspect of student learning, especially in their first years of university where the teacher is seen as 'a model knowledgeable adult' who not only has the power to develop students intellectually but also to help shape their identity as adults. Burgan (2006, p. 32) states that 'The two features of an individual instructor's pedagogy that most engage undergraduates are control of the material and concern with students' understanding of it'. Irrespective of the method of instruction and students' learning styles, what matters at the end of the day is that learning has occurred and students feel inspired and motivated to come back for more.

Table 1 summarizes the literature that has investigated the factors that influence student performance in finance and economics courses. 


\section{Table 1. Summary of Research on the Factors Influencing Student Success}

\begin{tabular}{|c|c|c|c|}
\hline Publication & Research Question/Aim & Data/Methodology & Results \\
\hline Fields (2013) & $\begin{array}{l}\text { The relationship between } \\
\text { prerequisite testing and } \\
\text { performance in upper- } \\
\text { level finance courses. }\end{array}$ & $\begin{array}{l}\text { The study analyzed whether scores of } 283 \text { students in the } \\
\text { mandatory prerequisite exam called Proficiency Exam influenced } \\
\text { the performance in Intermediate Finance. Pearson correlation and } \\
\text { ordinary least squares (OLS) regression was performed, } \\
\text { controlling for variables like GPAs, prerequisite Accounting } \\
\text { grades, gender and course timing. }\end{array}$ & $\begin{array}{l}\text { Prerequisite test scores were } \\
\text { related to the performance il } \\
\text { Accounting grade also influ } \\
\text { prerequisite exam helped stl } \\
\text { prepared for the upper-level } \\
\text { success. }\end{array}$ \\
\hline $\begin{array}{l}\text { Ashraf, Fendler, } \\
\text { and Shrikhande } \\
\text { (2013) }\end{array}$ & $\begin{array}{l}\text { The influence of learning } \\
\text { styles and personality } \\
\text { types on student } \\
\text { performance. }\end{array}$ & $\begin{array}{l}\text { Myers-Briggs personality types were assessed for } 74 \text { students } \\
\text { enrolled in Fundamentals of Valuation of Financial Assets. Grade } \\
\text { on the final exam was the dependent variable in the regression, } \\
\text { which contained questions from Bloom's five learning levels: } \\
\text { knowledge, comprehension, application, analysis and synthesis. }\end{array}$ & $\begin{array}{l}\text { The learning-style preferenc } \\
\text { performance. Students who } \\
\text { with performance while 'fee } \\
\text { performance decisions over: } \\
\text { significantly influence perfo } \\
\text { style preferences did influer } \\
\text { rather than visual learners p } \\
\text { students with global learnin } \\
\text { comprehension and analysis }\end{array}$ \\
\hline Mahbobi (2012) & $\begin{array}{l}\text { The relationship between } \\
\text { prior academic success in } \\
\text { high school and } \\
\text { probability of success and } \\
\text { failure in first-year } \\
\text { economics courses. }\end{array}$ & $\begin{array}{l}\text { A probit model was used to analyze final marks data from } 1369 \\
\text { students enrolled in Micro- and Macroeconomics course at } \\
\text { Thompson Rivers University for a period between } 2002 \text { and } \\
\text { 2009. Success or failure determinants included high school GPA, } \\
\text { age, gender, location of high school and type of high school. }\end{array}$ & $\begin{array}{l}\text { Age, location of student's h } \\
\text { and type of high school wer } \\
\text { Having no gap between the } \\
\text { university improved the like } \\
\text { chances of successfully com } \\
\text { given GPA score and regard } \\
\text { these courses was } 26 \text {. }\end{array}$ \\
\hline Rich (2006) & $\begin{array}{l}\text { Student effort and its } \\
\text { impact on performance. }\end{array}$ & $\begin{array}{l}\text { The sample consisted of } 230 \text { students enrolled in senior corporate } \\
\text { finance course required for all finance majors at Baylor } \\
\text { University. Effort was measured by attempted homework, } \\
\text { attendance and participation in class, while performance was } \\
\text { measured by exam result. A regression model was used to } \\
\text { analyze the data, controlling for student attributes with SAT math } \\
\text { and SAT verbal scores and a dummy variable for gender. }\end{array}$ & $\begin{array}{l}\text { Significant positive relation } \\
\text { days students had prepared } \\
\text { negative impact on perform: } \\
\text { had a positive influence. Stı } \\
\text { performed better in exams, } \\
\text { performance. }\end{array}$ \\
\hline $\begin{array}{l}\text { Bagamery, Lasik, } \\
\text { and Nixon (2005) }\end{array}$ & $\begin{array}{l}\text { What are the determinants } \\
\text { of success on Business } \\
\text { Major Field Exam? }\end{array}$ & $\begin{array}{l}\text { The sample contained } 169 \text { students who took the Educational } \\
\text { Testing Service (ETS) Field Exam in Business, enrolled in a } \\
\text { capstone business course at Central Washington University. } \\
\text { Factor analysis, correlation and regression models were } \\
\text { employed to obtain the results. }\end{array}$ & $\begin{array}{l}\text { There was no significant dif } \\
\text { majors and Business majors } \\
\text { at all. Male students who to } \\
\text { highest scores on the ETS B }\end{array}$ \\
\hline $\begin{array}{l}\text { Bale and Dudney } \\
(2000)\end{array}$ & $\begin{array}{l}\text { Investigates teaching } \\
\text { strategies that incorporate } \\
\text { adult learning theory } \\
\text { applied to undergraduate } \\
\text { finance students. }\end{array}$ & $\begin{array}{l}\text { Five-point Likert-scale survey of } 374 \text { college students enrolled in } \\
\text { finance courses at three public and two private institutions. }\end{array}$ & $\begin{array}{l}\text { Significant preference for p } \\
\text { clear communication of cou } \\
\text { preference than males for ac } \\
\text { incorporated past experienc } \\
\text { dependent on instructor for } \\
\text { as a second language prefer } \\
\text { working students had greate } \\
\text { classrooms. }\end{array}$ \\
\hline $\begin{array}{l}\text { Krishnan, Bathala, } \\
\text { Bhattacharya, and } \\
\text { Ritchey (1999) }\end{array}$ & $\begin{array}{l}\text { Students' perceptions and } \\
\text { expectations about } \\
\text { introductory finance } \\
\text { course. }\end{array}$ & $\begin{array}{l}\text { Two surveys conducted at the beginning and end of the semester } \\
\text { on } 386 \text { and } 275 \text { students, respectively. Correlation and factor } \\
\text { analysis was used in evaluating the results. }\end{array}$ & $\begin{array}{l}\text { The students found the cour } \\
\text { interesting with most studen } \\
\text { course if it were not require } \\
\text { course to be more difficult } t \\
\text { considered the course to be } \\
\text { covered highly quantitative }\end{array}$ \\
\hline $\begin{array}{l}\text { Didia and Hasnat } \\
\text { (1998) }\end{array}$ & $\begin{array}{l}\text { Examines the } \\
\text { determinants of student } \\
\text { performance in an }\end{array}$ & $\begin{array}{l}\text { Survey of } 210 \text { students enrolled in first-year finance courses at } \\
\text { State University of New York. Multiple regression analysis was } \\
\text { used where the dependent variable 'grade' was a function of }\end{array}$ & $\begin{array}{l}\text { Strong positive relationship } \\
\text { performance in accounting, } \\
\text { performance in finance cour }\end{array}$ \\
\hline
\end{tabular}




\begin{tabular}{|c|c|c|c|}
\hline & $\begin{array}{l}\text { introductory finance } \\
\text { course. }\end{array}$ & $\begin{array}{l}\text { GPA, hours of study, load per semester, average grade in } \\
\text { accounting and economics and math, age, and dummy gender } \\
\text { variable. }\end{array}$ & $\begin{array}{l}\text { influence on grade while ef } \\
\text { negatively related to final c } \\
\text { determining performance. }\end{array}$ \\
\hline $\begin{array}{l}\text { Chan, Shum, and } \\
\text { Wright (1997) }\end{array}$ & $\begin{array}{l}\text { Investigates the effect of } \\
\text { class attendance on } \\
\text { performance of finance } \\
\text { students. }\end{array}$ & $\begin{array}{l}\text { The overall score of } 48 \text { students enrolled in the control class and } \\
15 \text { students in the treatment class where } 15 \% \text { attendance bonus } \\
\text { was offered. Control factors such as GPA, load, work hours and } \\
\text { demographics were obtained from surveys and were used in } \\
\text { Tobit and Heckman's two-stage regressions. }\end{array}$ & $\begin{array}{l}\text { Significant positive relation } \\
\text { on performance using the T } \\
\text { relationship between attend } \\
\text { two-stage model where fina } \\
\text { variables in the regression. } \\
\text { policy did not improve perf }\end{array}$ \\
\hline $\begin{array}{l}\text { Sen, Joyce, Farrell, } \\
\text { and Toutant (1997) }\end{array}$ & $\begin{array}{l}\text { Is there a difference in } \\
\text { performance between } \\
\text { business and non-business } \\
\text { students enrolled in } \\
\text { introductory finance } \\
\text { course? }\end{array}$ & $\begin{array}{l}\text { A survey was conducted on } 426 \text { students at Michigan } \\
\text { Technological University (MTU) where } 9 \% \text { were finance majors, } \\
68 \% \text { were non-finance and } 22 \% \text { were non-business majors. } \\
\text { Separately, } 427 \text { students were surveyed at University of } \\
\text { Nebraska-Lincoln (UNL) where } 15 \% \text { were finance majors, } 58 \% \\
\text { non-finance and } 26 \% \text { non-business majors. OLS and ordered- } \\
\text { probit regressions were used to explain student performance. }\end{array}$ & $\begin{array}{l}\text { Finance and non-business } \\
\text { relative to the average busin } \\
\text { the two institutions: finance } \\
\text { MTU, while at UNL the no } \\
\text { GPA and prerequisites wer } \\
\text { performance. }\end{array}$ \\
\hline
\end{tabular}




\section{Methodology}

\subsection{Data sample and course design}

To address the research questions, an undergraduate course has been selected, which was convened and taught by the authors. This was a core second-year course in a Bachelor of Commerce program with Finance major. The course is offered on campus in face-to-face mode and had an enrolment of 120 students at the beginning of the semester. Seven students withdrew from the course during the semester, and thus grades were recorded for 113 students at the end of the semester. The course was run over a 13 -week semester with three contact hours per week, including two-hour lectures for the whole class and one-hour tutorials for smaller groups of up to 25 students. The assessment strategy consisted of a midsemester exam, group assignment and final examination. As per university policy requirements, all lectures were recorded and made available to the students immediately after the class. Tutorials were not recorded. Students had online access to all lecture slides, tutorial questions and answers in advance of their classes.

To undertake the quantitative analysis, the following data was collected: attendance roll for face-to-face classes; record of students' access to lecture slides, tutorial questions and answers; date, time and duration of student access to recorded videos of lectures. Students were also asked to complete a short survey on their use of textbooks for the course.

\subsection{Methodology}

To measure the impact of the various learning aids that students might have used in their studies, we regressed each of the variables described above against the overall scores (from zero to 100) that were achieved by students in the course. Because there are other important variables that may affect students' performance in the course, we collected and incorporated data for two such variables for use as controls in our regressions. First, the students' cognitive and analytical ability was tested using Raven's Progressive Matrices (adapted from Mironova, 2006). Around half of the students took this test. Second, students' English language ability was measured based on the result of an English Grammar and Comprehension Test (adapted from University of Wisconsin, 2016), attempted by about half the students in the course. We also used an alternate measure, a dummy for non-native English speakers, which was available for the whole class.

The generic equation used to measure the impact of various learning tools on success in the course is: 
Score $_{i}=a+\beta_{1} \times C L H_{i}+\beta_{2} \times O R_{i}+\beta_{3} \times L S_{i}+\beta_{4} \times T Q_{i}+\beta_{5} \times T A_{i}+\beta_{6} \times T R_{i}+\beta_{7} \times C A_{i}+\beta_{8} \times E L_{i}+\varepsilon_{i}$

The explanatory variables used in the regression are as follows:

- $\quad$ CLH represents the number of class hours students attended during the semester. This includes two hours of lectures and one hour of tutorial each week.

- $O R$ represents the volume of online recordings of lectures students accessed. The measure used is an average (\%) completion of recorded lectures. When students have not listened to the recording at all they are assigned a score of $0 \%$, whereas when the recording was streamed in full, the score is $100 \%$.

- $L S$ represents the number of lecture slides students downloaded from the course website. Lecture slides might be used by the student as an aid during the class, where they can make notes, but also can serve as a complementary learning and revision resource.

- $T Q$ represents the number of tutorial tasks students downloaded from the course website. It is a proxy of students' willingness to prepare for tutorial classes or self-study.

- TA represents the number of files with tutorial answers each individual student downloaded. Again, tutorial answers can be used as learning resources by the students to check their work or to assist in understanding the solutions to the prescribed problems.

- $\quad T R$ reflects how many chapters of prescribed textbook reading students have done. This information was collected through a survey, which was completed by 91 students.

- $\quad C A$ represents a proxy for cognitive and analytical ability.

- EL represents a proxy for English language ability.

The analysis was conducted in a number of stages. In the first stage, we reviewed the statistical data on the students' use of the teaching and learning tools in the course. In the second stage, we performed an overall regression analysis and conducted some sensitivity tests. We expected all tested variables to have a positive relationship with the overall score in the course. In the final stage, we investigated the issue of complementarity/substitutability of recorded classes by using correlation analysis and interactive terms in the regression model. 


\section{What did students prefer?}

We started the analysis by examining the data collected for each of the learning tools available to the students in the course. The inspection of data shows that all students who completed the course used at least one learning tool in their studies. The highest uptake was for downloaded lecture slides and tutorial questions and answers, where nearly all students downloaded some of the files. In fact, more than $90 \%$ of the students downloaded all such files from the course website. This indicates that all of the students who completed the course had an intention of putting some effort into their studies. Nevertheless, the mere fact that students have downloaded the files does not mean that those resources were effectively utilized. It comes as no surprise that uptake of other learning tools, where much more effort and time is required, was significantly lower.

Massingham and Herrington (2006) documented a trend of falling attendance rates for faceto-face classes over the preceding decade. We observed a similar trend, particularly since the practice of recording lectures began, is an average attendance rate that stands at just under $40 \%$ for both lectures and tutorials. If we exclude completely disengaged students - those who have not attended a single class - the attendance rate is above $40 \%$. It is interesting to note the difference between lectures and tutorials, with a striking contrast in terms of the number of students who either did not attend a single lecture or a single tutorial: nearly $10 \%$ of students never attended a lecture and nearly $25 \%$ of the students never attended a tutorial. The vast majority of those who attended at least one lecture and tutorial came back to at least one more lecture (83.19\%) or tutorial (92.92\%). Looking at the attendance patterns, it appears that some students were strategic in their attendances and joined the class in the weeks leading up to assessment events.

In Australia, it is typically expected that students secure access to textbooks themselves, either by purchasing them or borrowing from the library, friends or otherwise. To secure stable access to a textbook, purchasing it is typically the best option. Since purchasing textbooks requires a sizable investment of over 500 Australian dollars per semester, a significant number of students try their luck without reading the books concerned. From the survey we conducted, $58.41 \%$ of students claimed that they read at least a section of the prescribed reading. Those who attempted to read the textbook claimed that they read, on average, fewer than $34 \%$ of the total readings required. 
Finally, it was interesting to observe the uptake of recorded lectures as a learning resource. From conversations with colleagues, and based on personal observations, there is a perception that attendance rates for face-to-face classes have fallen by at least $20 \%$ since the introduction of recorded lectures. This may mean that a sizable number of students have decided to opt for the convenience of listening to the lectures in their own time. Looking at our raw data, we could not find unequivocal evidence of a substitution effect. Some students who did not attend the class did, indeed, show high rates of uptake of the recorded lecture streaming service. However, there were others who attended the face-to-face classes and also listened to the recorded lectures - we refer to this as a complementary effect. Finally, there were also some students who neither attended classes regularly, nor listened to recorded lectures. Perhaps a proportion of these students overestimated their ability to self-motivate and be disciplined. They might have had an intention of substituting the face-to-face classes with listening to the recordings but never actually got around to it.

Table 2 provides a summary of students' uptake of the learning resources in the course.

Table 2. Uptake of Learning Resources in the Course

\begin{tabular}{|c|c|c|c|c|}
\hline $\begin{array}{l}\text { Type of learning } \\
\text { resource }\end{array}$ & $\begin{array}{c}\text { Average } \\
\text { percentage, } \\
\text { overall }\end{array}$ & $\begin{array}{c}\text { Average } \\
\text { percentage } \\
\text { excluding non- } \\
\text { attempting } \\
\text { students }\end{array}$ & $\begin{array}{l}\text { Percentage of } \\
\text { students who } \\
\text { did not access } \\
\text { the resource }\end{array}$ & $\begin{array}{l}\text { Percentage } \\
\text { of students } \\
\text { who } \\
\text { accessed the } \\
\text { resources } \\
\text { once only }\end{array}$ \\
\hline Class attendance & 37.89 & 40.39 & 6.19 & 9.73 \\
\hline incl. lectures & 38.29 & 42.42 & 9.73 & 13.27 \\
\hline tutorials & 36.99 & 49.17 & 24.78 & 7.08 \\
\hline Recorded lectures & 8.83 & 13.86 & 36.28 & 16.81 \\
\hline $\begin{array}{l}\text { Prescribed book } \\
\text { chapters read }\end{array}$ & 19.82 & 33.93 & $41.59^{*}$ & 1.77 \\
\hline $\begin{array}{l}\text { Lectures slides } \\
\text { downloaded }\end{array}$ & 95.82 & 96.67 & 0.88 & $6.19 * *$ \\
\hline $\begin{array}{l}\text { Tutorial } \\
\text { questions } \\
\text { downloaded }\end{array}$ & 96.37 & 97.23 & 0.88 & $4.42 * *$ \\
\hline $\begin{array}{l}\text { Tutorial answers } \\
\text { downloaded }\end{array}$ & 94.87 & 96.58 & 1.77 & $7.96^{* *}$ \\
\hline
\end{tabular}

\section{What contributed the most toward success in the class?}


In the second stage of our analysis, we examined whether students' use of any of the learning tools made available to them contributed to their success in the course. We applied Equation (1) and regressed all explanatory variables that represent the learning tools, together with the control variables, against the students' score in the class. The results are presented in Table 3.

Table 3. Determinants of Success

\begin{tabular}{lccc}
\hline \multicolumn{4}{c}{ Dependent variable: Score } \\
$\begin{array}{l}\text { Independent } \\
\text { variable }\end{array}$ & $\begin{array}{c}\text { Coefficient } \\
(\boldsymbol{p} \text {-value })\end{array}$ & $\begin{array}{l}\text { Independent } \\
\text { variable }\end{array}$ & $\begin{array}{c}\text { Coefficient } \\
(\boldsymbol{p} \text {-value })\end{array}$ \\
\hline Constant & 0.562 & TA & -0.904 \\
& $(0.976)$ & TR & $(0.604)$ \\
CLH & $\mathbf{0 . 5 2 8}$ & & 0.981 \\
& $\mathbf{( 0 . 0 1 2 )}$ & CA & $(0.106)$ \\
OR & $\mathbf{0 . 2 6 2}$ & & $\mathbf{0 . 6 9 3}$ \\
& $\mathbf{( 0 . 0 3 2 )}$ & EL & $\mathbf{( 0 . 0 0 1 )}$ \\
LS & -0.722 & & $\mathbf{0 . 6 6 7}$ \\
& $(0.200)$ & & $\mathbf{( 0 . 0 2 3 )}$ \\
TQ & 2.459 & & \\
& $(0.198)$ & No. observations & \\
\hline R-squared & 0.504 & & \\
Adjusted R- & 0.399 & & \\
squared & & &
\end{tabular}

The results of the main estimation show mixed outcomes for the various learning resources available to the students. The class attendance variable (CLH) is positive and significant in the estimations, as expected. On average, an extra hour of class attendance added 0.528 to the final score. Similarly, the variable that represents access to recorded lectures $(\mathrm{OR})$ provided a positive and significant result. Students gained an average of 0.262 in their final score for each additional one per cent of completion of class recordings. Other learning resources did not generate significant results at any conventional level. The highest level of significance below conventional level at $89 \%$ has the measure representing textbook use (TR).The positive coefficient indicated that an extra chapter of reading added approximately one extra point to the total score for the course. The results for downloading teaching material from the web have not yielded significant results. Indeed, coefficients for the downloading of lecture slides (LS) and tutorial answers (TA) came out negative, which are hardly surprising results: the fact that students downloaded the files does not imply that they necessarily put any effort into then utilizing the materials in any beneficial manner. 
As predicted, the control variables representing cognitive and analytical ability (CA) and English language level (EL) are positive and significant. Overall, the regression has a rather high R-squared level and an insignificant constant, meaning that the model is well specified and rather robust.

To check the dependency of the model on the choice of proxies, we conducted a sensitivity analysis. In the first sensitivity test, we replaced the class attendance variable (CLH) with two variables, reflecting lecture (LH) and tutorial attendance $(\mathrm{TH})$. In the second sensitivity test, we replaced the variable that represents use of recorded lectures (OR). Instead of completion rate, we used the number of unique videos viewed (irrespective of the length of video streaming). In the third sensitivity test, we replace the proxy that represents the use of textbooks (TR). Instead of the number of full chapter readings, we used the number of unique chapters read (irrespective of whether the chapter was read in full or partially). In the fourth sensitivity test, we replaced the variable that represents the score for the English language test with the dummy variable that represents native English speakers. The results of these sensitivity tests are shown in Table 4.

Table 4. Results of Sensitivity Tests

\begin{tabular}{|c|c|c|c|c|}
\hline \multicolumn{5}{|c|}{ Dependent variable: Score } \\
\hline $\begin{array}{l}\text { Independent } \\
\text { variable }\end{array}$ & $\begin{array}{c}1 \\
\text { Coefficient } \\
(p \text {-value })\end{array}$ & $\begin{array}{c}2 \\
\text { Coefficient } \\
(p \text {-value })\end{array}$ & $\begin{array}{c}3 \\
\text { Coefficient } \\
(p \text {-value })\end{array}$ & $\begin{array}{c}4 \\
\text { Coefficient } \\
(p \text {-value })\end{array}$ \\
\hline Class attendance & & $\begin{array}{c}0.487 \\
(0.022)\end{array}$ & $\begin{array}{c}0.586 \\
(0.006)\end{array}$ & $\begin{array}{c}0.609 \\
(0.003)\end{array}$ \\
\hline $\begin{array}{l}\text { Completion rate of } \\
\text { streaming recorded } \\
\text { lectures }\end{array}$ & $\begin{array}{c}0.246 \\
(0.045)\end{array}$ & & $\begin{array}{c}0.308 \\
(0.0109)\end{array}$ & $\begin{array}{c}0.222 \\
(0.067)\end{array}$ \\
\hline $\begin{array}{l}\text { Lecture slides } \\
\text { downloaded }\end{array}$ & $\begin{array}{l}-0.748 \\
(0.184)\end{array}$ & $\begin{array}{l}-0.654 \\
(0.257)\end{array}$ & $\begin{array}{l}-0.617 \\
(0.280)\end{array}$ & $\begin{array}{c}0.041 \\
(0.949)\end{array}$ \\
\hline $\begin{array}{l}\text { Tutorial questions } \\
\text { downloaded }\end{array}$ & $\begin{array}{c}2.924 \\
(0.136)\end{array}$ & $\begin{array}{c}2.769 \\
(0.157)\end{array}$ & $\begin{array}{c}2.587 \\
(0.195)\end{array}$ & $\begin{array}{c}2.408 \\
(0.275)\end{array}$ \\
\hline $\begin{array}{l}\text { Tutorial answers } \\
\text { downloaded }\end{array}$ & $\begin{array}{l}-1.387 \\
(0.442)\end{array}$ & $\begin{array}{l}-0.919 \\
(0.612)\end{array}$ & $\begin{array}{l}-1.008 \\
(0.583)\end{array}$ & $\begin{array}{l}-1.120 \\
(0.577)\end{array}$ \\
\hline $\begin{array}{l}\text { Textbook reading - } \\
\text { no. of full chapter } \\
\text { equivalents }\end{array}$ & $\begin{array}{c}1.070 \\
(0.081)\end{array}$ & $\begin{array}{c}1.118 \\
(0.073)\end{array}$ & & $\begin{array}{c}0.912 \\
(0.121)\end{array}$ \\
\hline $\begin{array}{l}\text { Cognitive and } \\
\text { analytical ability } \\
\text { test }\end{array}$ & $\begin{array}{c}0.722 \\
(0.001)\end{array}$ & $\begin{array}{c}0.605 \\
(0.004)\end{array}$ & $\begin{array}{c}0.694 \\
(0.002)\end{array}$ & $\begin{array}{c}0.755 \\
(0.001)\end{array}$ \\
\hline
\end{tabular}




\begin{tabular}{|c|c|c|c|c|}
\hline $\begin{array}{l}\text { English ability - } \\
\text { test result }\end{array}$ & $\begin{array}{c}0.665 \\
(0.023)\end{array}$ & $\begin{array}{c}0.710 \\
(0.019)\end{array}$ & $\begin{array}{c}0.580 \\
(0.046)\end{array}$ & \\
\hline Lecture attendance & $\begin{array}{c}0.334 \\
(0.667) \\
\end{array}$ & & & \\
\hline Tutorial attendance & $\begin{array}{c}1.146 \\
(0.065)\end{array}$ & & & \\
\hline $\begin{array}{l}\text { No. of unique } \\
\text { recordings streamed }\end{array}$ & & $\begin{array}{c}0.730 \\
(0.101)\end{array}$ & & \\
\hline $\begin{array}{l}\text { Textbook reading - } \\
\text { no. of unique } \\
\text { chapters read }\end{array}$ & & & $\begin{array}{c}0.410 \\
(0.308)\end{array}$ & \\
\hline $\begin{array}{l}\text { English ability - } \\
\text { English native } \\
\text { speaker dummy }\end{array}$ & & & & $\begin{array}{c}5.681 \\
(0.158)\end{array}$ \\
\hline R-squared & 0.522 & 0.474 & 0.480 & 0.273 \\
\hline Adjusted R-squared & 0.403 & 0.362 & 0.369 & 0.158 \\
\hline No. observations & 41 & 41 & 41 & 52 \\
\hline
\end{tabular}

Note. Bold indicates significant at a conventional level.

The results of the sensitivity tests are encouraging in two aspects. Firstly, they confirm that the choice of variables for the original estimation was correct. Not only are those variables the best available proxies from a theoretical point of view, they also provided the best estimation results. Secondly, the core variables in the estimations remained practically unchanged, which confirms the robustness of our findings. Explanatory variables, such as class attendance, access to online recordings and the control variables for English ability and cognitive and analytical ability, remained positive and significant in all estimations with stable coefficients. The variables representing the download of materials remained insignificant in all estimations, with reasonably stable coefficients. The only variable that became significant at the $90 \%$ level in two out of three sensitivity tests is the proxy for textbook use. However, this is not surprising as the same variable was significant at $89 \%$ in the original estimations. The estimated coefficient for the textbook use remains rather stable around one.

As for the substitute variables, most of them turned out to be insignificant, although having a positive coefficient. The only exception was the sensitivity test in which we decomposed the class attendance variable into separate variables for lecture and tutorial attendances. The tutorial attendance variable showed a much higher coefficient and greater statistical significance at $90 \%$. This is not a surprising result because tutorials are normally run in smaller groups and in a more interactive manner, and typically require much stronger focus 
and effort from the students. In contrast, due to the larger size of the lecture classes and the consequently less interactive nature of their delivery, students are less likely to be able to maintain a strong and consistent focus on learning and absorbing the material taught.

\section{Recording lecture videos - substitutes for or complements to traditional lectures?}

In this section, we examine how students treated various learning resources, whether some of them act as substitutes or whether they might complement each other. This is achieved by analyzing the correlations between variables, and the resulting correlation matrix is presented in Table 5.

Table 5. Correlation Matrix for Learning Variables

\begin{tabular}{c|cccccccc} 
& Score & LH & TH & OR & LS & TQ & TA & TR \\
\hline Score & 1.000 & 0.306 & 0.415 & 0.272 & -0.082 & 0.227 & 0.155 & 0.125 \\
LH & 0.306 & 1.000 & 0.635 & -0.203 & 0.027 & -0.017 & -0.088 & 0.131 \\
TH & 0.415 & 0.635 & 1.000 & -0.103 & 0.073 & 0.066 & 0.068 & 0.092 \\
OR & 0.272 & -0.203 & -0.103 & 1.000 & 0.112 & 0.052 & 0.003 & 0.329 \\
LS & -0.082 & 0.027 & 0.073 & 0.112 & 1.000 & -0.087 & -0.110 & 0.192 \\
TQ & 0.227 & -0.017 & 0.066 & 0.052 & -0.087 & 1.000 & 0.910 & -0.038 \\
TA & 0.155 & -0.088 & 0.068 & 0.003 & -0.110 & 0.910 & 1.000 & -0.008 \\
TR & 0.125 & 0.131 & 0.092 & 0.329 & 0.192 & -0.038 & -0.008 & 1.000
\end{tabular}

Table 5 shows that only two pairs of measures displayed high positive levels of correlation coefficient. The correlation between downloading tutorial questions (TQ) and downloading tutorial answers (TA) has a coefficient of 0.91 , which means that students have mostly accessed both files at the same time. Another pair of variables that show relatively high correlation $(0.635)$ is lecture attendance $(\mathrm{LH})$ and tutorial attendance $(\mathrm{TH})$, which means that many students who attended lectures also attended tutorials. On the other hand, this coefficient is perhaps not as high as expected and may have been impacted by scheduling issues: not all tutorials were offered in a time slot adjacent to lectures. In general, attendance rates for tutorials scheduled immediately before or after a lecture class are usually higher. 
Looking at the correlation of various learning resources with the final course result, we can confirm the general argument presented earlier. Tutorial attendance and lecture attendance, followed by the streaming of recorded lectures, have the highest positive correlations with the overall result. All learning resources have positive correlation coefficients apart from downloaded lecture slides, which show a marginally negative correlation coefficient.

Finally, we examined the relationship between the attendance of face-to-face classes and the streaming of online recordings. We observed that students tended to view attendance of the classes and online streaming more as substitute than complementary activities, displaying small negative correlation coefficients. Because only lectures were recorded and posted online, the negative correlation coefficient between face-to-face and recorded lectures is, naturally, higher at -0.203 . In addition, there is a negative correlation between tutorial attendance and the streaming of recorded lectures, which suggests that some of the students made a deliberate choice to study independently with the use of online resources, and opted not to attend on-campus classes altogether.

In this study we extended our analysis of the relationship between class attendance and online resources beyond students' preferences by investigating whether there was benefit from using both resources together. Anecdotally, some students, notably international students, found recorded lectures a useful complementary tool, enabling them to return and listen to sections of the lectures that they have not understood in class.

To test whether there is such complementarity and whether there is evidence that accessing both live and recorded lectures adds tangible benefits in the form of higher marks, we ran another regression, where we added an interactive term. This interactive term (IT) is the product of the variables for lecture attendance $(\mathrm{LH})$ and access to online recordings $(\mathrm{OR})$, and was added to the regression where we had separate variables for lectures and tutorials. The results of the consequent regression analysis are presented in Table 6. 
Table 6. Results of the Regression Using an Interactive Term

\begin{tabular}{|c|c|c|c|}
\hline \multicolumn{4}{|c|}{ Dependent variable: Score } \\
\hline $\begin{array}{l}\text { Independent } \\
\text { variable }\end{array}$ & $\begin{array}{c}\text { Coefficient } \\
(p \text {-value })\end{array}$ & $\begin{array}{l}\text { Independent } \\
\text { variable }\end{array}$ & $\begin{array}{c}\text { Coefficient } \\
\text { (p-value) }\end{array}$ \\
\hline LH & $\begin{array}{c}0.045 \\
(0.962)\end{array}$ & TQ & $\begin{array}{c}2.829 \\
(0.155)\end{array}$ \\
\hline TH & $\begin{array}{c}1.184 \\
(0.061)\end{array}$ & TA & $\begin{array}{c}-1.297 \\
(0.478)\end{array}$ \\
\hline IT & $\begin{array}{c}0.033 \\
(0.596)\end{array}$ & TR & $\begin{array}{c}1.162 \\
(0.073)\end{array}$ \\
\hline OR & $\begin{array}{c}0.129 \\
(0.607)\end{array}$ & $\mathbf{C A}$ & $\begin{array}{c}0.751 \\
(0.001)\end{array}$ \\
\hline LS & $\begin{array}{l}-0.794 \\
(0.169)\end{array}$ & $\mathbf{E L}$ & $\begin{array}{c}0.669 \\
(0.024)\end{array}$ \\
\hline $\begin{array}{l}\text { R-squared } \\
\text { Adjusted R- } \\
\text { squared }\end{array}$ & $\begin{array}{l}0.526 \\
0.389\end{array}$ & No. observations & 41 \\
\hline
\end{tabular}

As is evident from the results shown in Table 6, the interactive term has a small positive coefficient, suggesting some tendency toward complementarity. However, the result is insignificant at any conventional level, suggesting that this cannot be argued with confidence. All the other variables gave similar results as in previous regressions, apart from results for recorded and live lectures where both variables saw a reduction in coefficients and lower significance.

In summary, there is no strong evidence that following both live and recorded lectures presented additional benefits to the students. Indeed, students tended to see these two items more as substitutes for one another.

\section{Conclusion}

In this paper, we have examined three major questions. Firstly, we have analyzed which teaching resources provided were used by the students in a second-year finance course. We found that students typically demonstrated their intention to put in effort by downloading the lecture slides, tutorial exercises and answers. However, for the resources that required more effort time, such as the attendance of classes and the viewing of streamed lecture recordings, the usage rate was much lower. The average attendance rates of tutorials and lectures were similar, although the proportion of students who did not attend a single tutorial class is rather 
high at around $25 \%$ and higher than the proportion (under $10 \%$ ) who did not attend a single lecture. The rate of use of recorded lectures was slightly smaller at just under $9 \%$.

Secondly, we used regression analysis to establish which of the resources contributed the most to students' success. We showed that both class attendance and the streaming of recorded lectures provided positive and significant coefficients, which means both learning strategies are useful for achieving success in the course. Comparing which face-to-face hours were more beneficial - lectures versus tutorials, the latter proved to be more effective for student success. This is likely to be attributable to the smaller size and higher level of interactivity of the tutorial environment, which encourages students to focus more on their studies. This provides some indirect evidence that adopting more interactive teaching strategies is likely to be beneficial in ensuring student success.

Reading the textbook seems to be helpful in aiding achievement in the course. The use of other resources, such as downloading tutorial questions, answers and lecture slides, does not show significance at conventional levels. In our study, we controlled for other important variables, such as cognitive ability and English language level. As expected, both measures are positive and significant.

Thirdly, we looked at the relationship between the live and recorded lectures and found no evidence that these are complementary in terms of providing benefits for student success in the finance course. Indeed, it appears that students are more likely to use these resources as substitutes for each other. In general, students who came to class did not listen to the recordings, whereas those who listened to the recordings did not come to the class.

As a final remark, it appears that students who succeeded in the course were the ones who could tailor the study strategy for themselves and follow that strategy. Those making little effort proved to be the ones who failed the course.

The analysis in this paper provides valuable food for thought for both academics and university managers. Firstly, face-to-face interactions remain a valuable teaching and learning resource. The student's active participation should be continuously encouraged by various means, including the application of various active learning strategies. Secondly, it appears that the availability and use of online resources represent a valuable resource for students who are unable or unwilling to engage in face-to-face interaction with their instructors. 


\section{References}

Akimov, A., \& Malin, M. (2017). Are classroom games useful for teaching 'sticky' finance concepts? Evidence from a swap game. Advances in Financial Education, 15(1), forthcoming.

Amador, J. A., Miles, L., \& Peters, C. B. (2006). The practice of problem-based learning: A guide to implementing PBL in the college classroom. San Francisco, CA: Jossey Bass.

Anderson, G., Benjamin, D. and Fuss, M. A. (1994). The determinants of success in university introductory economic courses. Journal of Economic Education, 25(2), 99-119.

Andrietti, V., \& Velasco, C. (2015). Lecture attendance, study time, and academic performance: A panel data study. Journal of Economic Education, 46(3), 239-259.

Ashraf, R., Fendler, R., \& Shrikhande, M. (2013). Impact of personality types and learning styles on performance of finance majors. Journal of Financial Education, 39(3/4), 47-68.

Bagamery, B. D., Lasik, J. J., \& Nixon, D. R. (2005). Determinants of success on the ETS Business Major Field Exam for students in an undergraduate multisite regional university business program. Journal of Education for Business, 81(1), 55-63.

Bale, J. M., \& Dudney, D. (2000). Teaching Generation X: Do andragogical learning principles apply to undergraduate finance education? Financial Practice and Education, 10(1), 216-227.

Berk, R. A. (2009). Multimedia teaching with video clips: TV, movies, YouTube, and mtvU in the college classroom. International Journal of Technology in Teaching and Learning, $5(1), 1-21$.

Biggs, J. B. (1989). Approaches to the enhancement of tertiary teaching. Higher Education Research and Development, 8(1), 7-25.

Bonesrønning, H., \& Opstad, L. (2012). How much is students' college performance affected by quantity of study? International Review of Economics Education, 12(2), 28-45.

Bosshardt, W., \& Watts, M. (1990). Instructor effects and their determinants in precollege economic education. Journal of Economic Education, 21(3), 265-276. 
Brown Wright, G. (2011). Student-centered learning in higher education. International Journal of Teaching and Learning in Higher Education, 23(3), 92-97.

Burgan, M. (2006). In defense of lecturing. Change: The Magazine of Higher Learning, $38(6), 30-34$.

Caldwell, J. E. (2007). Clickers in the large classroom: Current research and best-practice tips. CBE Life Sciences Education, 6(1), 9-20.

Chan, K. C., Shum, C., \& Wright, D. J. (1997). Class attendance and student performance in principles of finance. Financial Practice and Education, 7(2), 58-65.

Chen, J., \& Lin, T. F. (2008). Class attendance and exam performance: A randomized experiment. Journal of Economic Education, 39(3), 213-227.

Cohn, E., \& Johnson, E. (2006). Class attendance and performance in principles of economics. Education Economics, 14(2), 211-233.

Cooper, M. A. (1999). Classroom choices from a cognitive perspective on peer learning. In A. M. O’Donnell \& A. King (Eds.), Cognitive perspectives on peer learning (pp. 215-234). Hillsdale, NJ: Lawrence Erlbaum Associates.

Didia, D., \& Hasnat, B. (1998). The determinants of performance in the university introductory finance course. Financial Practice and Education, 8(1), 102-107.

Dobkin, C., Gil, R., \& Marion, J. (2010). Skipping class in college and exam performance: Evidence from a regression discontinuity classroom experiment. Economics of Education Review, 29(4), 566-575.

Draper, S. W., \& Brown, M. I. (2004). Increasing interactivity in lectures using an electronic voting system. Journal of Computer Assisted Learning, 20(2), 81-94.

Fields, L.P. (2013). Mandatory prerequisite testing and performance in intermediate corporate finance. Journal of Financial Education, 39 (1-2), 29-42

Ford, N., Bowden, M., \& Beard, J. (2011). Learning together: Using social media to foster collaboration in higher education. In L. A. Wankel and C. Wankel (Eds.), Higher education administration with social media (Cutting-edge technologies in higher education, Vol. 2, pp. 105-126). Bingley, UK: Emerald Group. 
Goffe, W. L., \& Kauper, D. (2014). A survey of principles instructors: Why lecture prevails. Journal of Economic Education, 45(4), 360-375.

Graves, O. F., Nelson, I. T., \& Deines, D. S. (1993). Accounting student characteristics: Results of the 1992 Federation of Schools of Accountancy (FSA) Survey. Journal of Accounting Education, 11(2), 221-225.

Hoffman, B., \& Ritchie, D. (1997). Using multimedia to overcome the problems with problem based learning. Instructional Science, 25(2), 97-115.

Johnson, D. L., Joyce, P., \& Sen, S. (2002). An analysis of student effort and performance in the finance principles course. Journal of Applied Finance, 12(2), 67-72.

Kaufer, D., Gunawardena, A., Tan, A., \& Cheek, A. (2011). Bringing social media to the writing classroom: Classroom salon. Journal of Business and Technical Communication, 25(3), 299-321.

Kilic, A. (2010). Learner-centered micro teaching in teacher education. International Journal of Instruction, 3(1), 77-100.

Krishnan, V. S., Bathala, C. T., Bhattacharya, T. K., \& Ritchey, R. (1999). Teaching the introductory finance course: What can we learn from student perceptions and expectations? Financial Practice and Education, 9(1), 70-82.

Laband, N. D., \& Piette, M. J. (1995). Does who teaches principles of economics matter? Papers and Proceedings of the American Economic Association, 85(2), 335-338.

Leiber, J. M., Crew, B. K., Wacker, M. E., \& Nalla, M. K. (1993). A comparison of transfer and nontransfer students majoring in criminology and criminal justice. Journal of Criminal Justice Education, 4(1), 133-151.

Lizzio, A., Wilson, K., \& Simons, R. (2002) University students' perceptions of the learning environment and academic outcomes: Implications for theory and practice. Studies in Higher Education, 27(1), 27-52.

Loyens, S. M. M., Magda, J., \& Rikers, R. M. J. P. (2008). Self-directed learning in problembased learning and its relationships with self-regulated learning. Educational Psychology Review, 20(4), 411-427. 
Mahbobi, M. (2012). What factors influence first-year students' success and failure at TRU: A case of introductory economics courses. Journal of Economics and Economic Education Research, 13(3), 133-143.

Marburger, D. R. (2001). Absenteeism and undergraduate exam performance. Journal of Economic Education, 32(2), 99-109.

Marton, F., \& Säljö, R. (1976). Symposium: Learning processes and strategies. On qualitative differences in learning II: Outcome as a function of the learner's conception of the task. British Journal of Educational Psychology, 46(2), 115-127.

Massingham, P., \& Herrington, T. (2006). Does attendance matter? An examination of student attitudes, participation, performance and attendance. Journal of University Teaching and Learning Practice, 3(2), 82-103.

Mironova, E. E. (Ed.). (2006). Collection of psychological tests. Part 2. Minsk: Envila Woman Institute.

Murphy, P. D., \& Stanga, K. G. (1994). The effects of frequent testing in an income tax course: An experiment. Journal of Accounting Education, 12(1), 27-41.

O’Donnell, A. M., Hmelo-Silver, C. E., \& Erkens, G. (Eds.). (2006). Collaborative learning, reasoning, and technology. Mahwah, NJ: Lawrence Erlbaum Associates.

Orlov, A. G., \& Roufagalas, J. (2012). Performance determinants in undergraduate economics classes: The effect of cognitive reflection. International Review of Economics Education, 11(2), 28-45.

Paulsen, B. M., \& Gentry, J. A. (1995). Motivation, learning strategies, and academic performance: A study of the college finance classroom. Financial Practice and Education, $5(1), 78-89$.

Piaget, J. (1926). The language and thought of the child. New York, NY: Harcourt, Brace \& Company.

Pintrich, P. R. (1994). Continuities and discontinuities: Future directions for research in educational psychology. Educational Psychologist, 29(3), 137-148. 
Pritchard, R. E., Romeo, G. C., \& Saccucci, M. S. (2000). Quantitative skills and performance in principles of finance: Evidence from a regional university. Financial Practice and Education, 10(2), 167-174.

Rich, S. P. (2006). Student performance: Does effort matter? Journal of Applied Finance, $16(2), 120-133$.

Rosenshine, B., \& Stevens, R. (1986). Teaching functions. In M. C. Wittrock (Ed.), Handbook of research on teaching (3rd ed., pp. 376-391). New York, NY: Macmillan.

Sen, S., Joyce, P., Farrell, K., \& Toutant, J. (1997). Performance in principles of finance courses by students with different specializations. Financial Practice and Education, 7(2), $66-73$.

Slavich, G. M., \& Zimbardo, P. G., (2012). Transformational teaching: Theoretical underpinnings, basic principles, and core methods. Educational Psychology Review, 24(4), 569-608.

Smith, M. K., Wood, W. B., Adams, W. K., Wieman, C., Knight, J. K., Guild, N., et al. (2009). Why peer discussion improves student performance on in-class concept questions. Science, 323(2), 122-124.

Stanca, L. (2006). The effects of attendance on academic performance: Panel data evidence for introductory microeconomics. Journal of Economic Education, 37(3), 251-266.

Stinebrickner, R., \& Stinebrickner, T. R. (2008). The causal effect of studying on academic performance. The B.E. Journal of Economic Analysis \& Policy, 8(1), 8-53.

Svinivki, M., \& McKeachie, W. J. (2011). McKeachie's teaching tips: Strategies, research, and theory for college and university teachers (13th ed.). Belmont, CA: Wadsworth.

Thomas, P. R., \& Bain, J. D. (1984). Contextual dependence of learning approaches: The effects of assessments. Human Learning, 3, 227-240.

University of Wisconsin-Madison (2016). English as a Second Language Assessment Test (ESLAT). Retrieved from https://english.wisc.edu/es1/international-students-placement.htm

Vermunt, J. D. (1996). Metacognitive, cognitive and affective aspects of learning styles and strategies: A phenomenographic analysis. Higher Education, 31(1), 25-50. 
Vermunt, J. D. (1998). The regulation of constructive learning processes. British Journal of Educational Psychology, 68(2), 149-171.

Vermunt, J. D., \& Vermetten, Y. J. (2004). Patterns in student learning: Relationships between learning strategies, conceptions of learning, and learning orientations. Educational Psychology Review, 16(4), 359-384.

Vygotsky, L. S. (1986). Thought and language (Rev. ed.). Cambridge, MA: MIT Press.

Wang, M. C., Haertel, G. D., \& Walberg, H. J. (1993). Toward a knowledge base for school learning. Review of Educational Research, 63(3), 249-294.

Williams, A., Birch, E., \& Hancock, P. (2012). The impact of online lecture recordings on student performance. Australasian Journal of Educational Technology, 28(2), 199-213. 